\title{
COMPARATIVE ANALYSIS OF FORMWORK IN MULTISTORY
} BUILDING

\author{
Sandip.P.Pawar ${ }^{1}$, P.M.Atterde ${ }^{2}$ \\ ${ }^{1}$ P.G. Student Deptt of civil Engineering SSGBCOET Bhusawal Maharashtra \\ ${ }^{2}$ Guide, Deptt of civil Engineering SSGBCOET Bhusawal Maharashtra
}

\begin{abstract}
One of the most important factors in determing the success of a construction project in terms of speed, quality cost and safety of work is the formwork used in the project as it accounts about $40 \%$ of the total project cost of the structure. When considering a construction project both the client and contractor want to finish the job early as the client wants to use the building for the intended purpose as soon as possible. The contractor wants to finish the construction as soon as possible to gain a higher profit. The most efficient way to speed up the work in high-rise building construction is by achieving a very short floor cycle. The floor cycle of a building mainly depend on the formwork type as it is the main time factor of a building project. The aim of this paper is to present about the existing formwork types in Maharashtra and to show each one will affect the project duration, project cost and the quality of the work. For that a research has been carried out and the results will present in this paper.
\end{abstract}

Keywords: Formwork,Duration,cost,quality

\section{INTRODUCTION}

Formwork is defined as temporary structure whos purpose is to provide support and containment for fresh concrete until it can support itself. It moulds the concrete to the desired shape and size and controls its position and alignment. The development of formworks is parallel with the growth of concrete construction throughout the 20th century. The advancement of technology, increase of population and the space limitation lead the way to construct high-rise buildings. But the task was not very easy at the beginning but now the man made the task easy by inventing new machinery and new techniques.

The most important factor in terms of cost, quality and speed in a high-rise building construction project is the type of the formwork used in the project. The first formwork type to be used is the conventional type formwork where the timber planks were supported on timber columns. With the advancement of technology it developed gradually and people used ply wood sheets instead of timber planks and steel pipes with jacks were used to support the ply wood. Then people invented small units of formworks and connect the repeating units in the construction. The larger units were invented like formworks for slab panels, formworks for columns, beams...etc. when the same elements are repeating. Then finally the whole system of formwork is made and initially the material used to it was steel and it was very heavy. Then the aim was to reduce the weight of the system and the materials for formwork have extended to aluminium, plastic, fiber glass...etc.

contractors are in a belief that the system formwork is suitable only for super tall buildings as the initial cost of the system formwork is a bit high. Though the initial cost of the system formwork is a bit high it reduces the project duration and hence the total project cost. When considering the overall construction of a high-rise building the system formwork is much more economical that to all the other primary formwork types as it reduces the project duration, gives a smooth concrete surface and the repetitive use of the system. This is suitable for even for a two or three storey housing scheme of several houses.

\section{TYPES OF FORMWORKS}

Conventional Formwork: This is the oldest type of formwork used in the construction industry. This type uses timber, bamboo, masonry and carpentry in the construction. This type is very much suitable for small houses with two to three storeys and still they are in use for such constructions. But this is not suitable for the big projects or high-rise buildings. Low initial cost, low experience factor, low weight are some of the advantages of this type and poor finish, high labor requirement, skilled labor. requirement and consume lot of time are some of the disadvantages.

Modern Conventional Formwork: This type is very much closer to the conventional formwork and in simple words this is one step advanced than the conventional type. The same technique has used in the both types and the only difference is the materials use for the formworks. In modern conventional formwork more advanced materials are used and they can reuse for several times. The differences of both types are that steel props and various types of jacks ( $U$ jacks, $\mathrm{T}$ jacks) are used as supports in the formwork instead of timber supports and ply wood sheets are used instead of timber planks on slab decks, beams and columns. Low initial cost, low skilled labor requirement, can even use in small places and when there are lot of deviations in the structure are some of the advantages while poor finish of the 
concrete surface, high labor requirement and the higher floor cycle are the disadvantages

This type is much more advanced than the modern conventional type. In this type there are pre-fabricated formwork items such as pre-fabricated formworks for slab panels and supports and ply wood should be used additionally for slab deck, beams and columns for the surface. There are other forms of semi system formwork such as table forms, flying forms...etc. DOCA is the most famous brand for this type of formwork and some people know about this type only as "DOCA formwork".

System Formwork: System formwork has prefabricated modular components with casting panels. The system formwork is fabricated as it suits the required shape. The biggest advantage of this type is the speedy and quality construction. But the high initial cost is the main disadvantage and hence it is not economical to use in low rise buildings. But this is the most economical form of formwork type to be used in high-rise building construction when it is having few typical storeys.

\section{RESEARCH STUDY}

The expectation of this study is to find the most economical formwork type to be used in a high-rise building project. When considering a construction project there are many cost components contributing to the total cost of the project. Preliminary cost is a key cost component when comparing the total cost of a project, and the duration of the project is the governing factor for the preliminary running cost.

Total Project Cost $=$ Materials and labour + Preliminary cost + Machinery \& equipment $\mathrm{t}+$ Waste material handling + Safety + Finishes $+\ldots$

Preliminary Cost $=$ Salaries + work establishment charge + Security ...

When a building construction project is considered the material requirement is unique as it depends on the design. But the labor requirement and the duration of the project are directly affected by the technologies and the construction methods used in the project. The speed of the project is directly affected by the formwork type used in the project. This is the most critical in high-rise building construction. When using latest technologies, the labor requirement and the time duration can beminimized in the project, mainly for the super structure.

In high-rise building projects time controlling factor is the formwork as it directly affect the floor cycle and hence it will reduce the time taken to construct the main structure and because of that the total duration of the project will go down drastically. In this research cost comparisons of total project cost has done for several projects when all the two types of formwork types are used in the same project.

\section{THE RESULTS}

\subsection{The Results Obtained}

Data is collected from M/s Sai Construction Ahmednagar .Name of Construction work on Residetial Building of KARAN RHEA Wing A,Wing B,\&Wing $\mathrm{C}$ at Wadegaon Sheri, Pune projects and calculations are done for the total project cost of the selected projects when using different types of formworks in the construction. In the calculations all the parameters are kept same and only the formwork type is changed. At the same time all the factors affect due to the formwork type is considered. The results can be shown in a table as follows.

Table .1

\begin{tabular}{|l|l|l|l|}
\hline Project & $\begin{array}{l}\text { No.of } \\
\text { Floor }\end{array}$ & $\begin{array}{l}\text { Area of } \\
\text { each } \\
\text { floor } \\
\text { (sam) }\end{array}$ & $\begin{array}{l}\text { Total cost of } \\
\text { Project }\end{array}$ \\
\hline Wing A & 10 & 418 & $11,24,42,000$ \\
\hline Wing B & 15 & 510 & $13,71,90,000$ \\
\hline Wing C & 20 & 600 & $16,14,40,000$ \\
\hline
\end{tabular}

Table .2

\begin{tabular}{|l|l|l|l|}
\hline \begin{tabular}{l} 
Analysis of the Aluminium formwork for \\
Typical Floor \\
\hline
\end{tabular} Wing A & Wing B & Wing C \\
\hline $\begin{array}{l}\text { Form work } \\
\text { cost in Laks }\end{array}$ & 9.82 & 11.98 & 14.1 \\
\hline $\begin{array}{l}\text { Waist disposal } \\
\text { cost in Laks }\end{array}$ & 0 & 0 & 0 \\
\hline $\begin{array}{l}\text { Machinary } \\
\text { cost in Laks }\end{array}$ & 0.9 & 1.12 & 1.98 \\
\hline
\end{tabular}

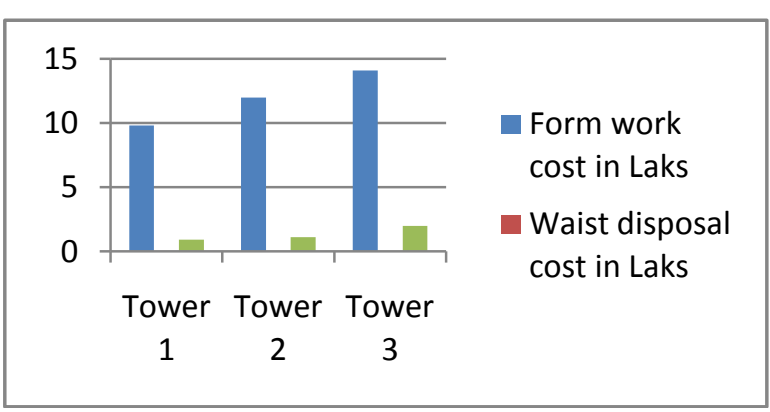

For Aluminium form work

Table 3

\begin{tabular}{|l|l|l|l|}
\hline \multicolumn{4}{|c|}{ Analysis of the conventional formwork for } \\
Typical Floor \\
\hline & Wing A & Wing B & Wing C \\
\hline $\begin{array}{l}\text { Form work } \\
\text { cost in Laks }\end{array}$ & 6.27 & 7.65 & 9.0 \\
\hline $\begin{array}{l}\text { Waist disposal } \\
\text { cost in Laks }\end{array}$ & 0.31 & 0.38 & 0.45 \\
\hline
\end{tabular}



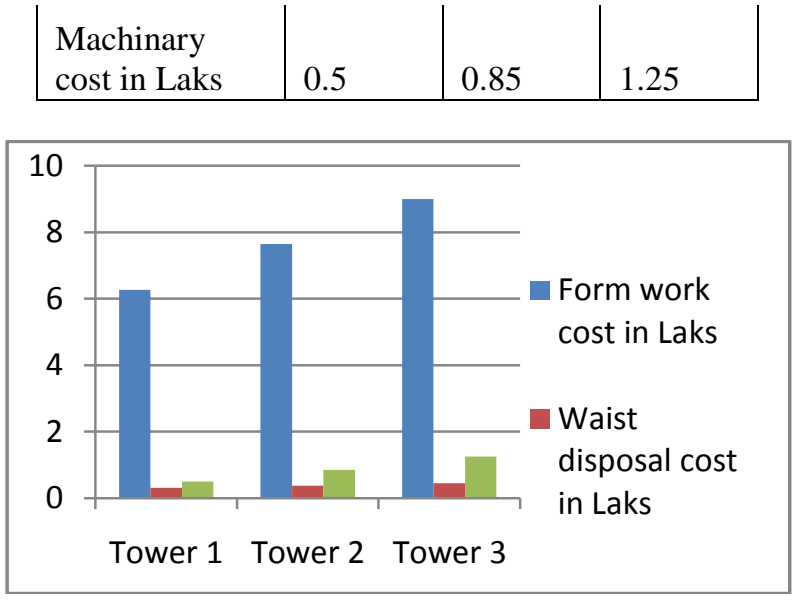

For Conventional Form work

\section{CONCLUSIONS}

From the results obtained we can come to a conclusion that when the system formwork is used in the construction project, the total project cost and the duration of the project is lesser than the other formwork types.

The main important thing is that the aluminium panel system formwork is the most expensive formwork type from those three types. At the same time the highest total project cost is obtained when modern conventional type of formwork is used in the building construction project which is the least expensive formwork type. So it is clearly seen that that not the cost of formwork directly affected to the total project cost but the type of formwork.

The floor cycle will be 6-10 days when the system formwork is in use and hence the total project duration will be reduced. At the same time a smooth concrete surface can be obtained as the system can be assembled without any discontinuities in the surface and hence less finishing work will be there and hence the cost for finishes will be reduced. There will be less waste disposal and less machinery usage. Not only the direct benefits, there are many indirect benefits of using aluminium panel system formwork in the high-rise building construction projects. For example the system can be sold after using, it can be used in other slabs doing slight variations (there is no need to buy materials again).

\section{REFERENCES}

[1] Hurd, M.K. 1989. Formwork for Concrete, 6th ed. American Concrete Institute, Detroit, MI.

[2] Nolan, É. Innovation in concrete frame construction 1995-2015. IHS BRE Press, Garston. BR 483. 44pp

[3] Moore, C.E. 1977. Concrete Form Construction. Van Nostrand Reinhold, New York.

[4] Ratay, R.T. 1984. Handbook of Temporary Structures in Construction. McGraw-Hill, New York

[5] Peurifoy, P.E. 1976. Formwork for Concrete Structures. McGraw-Hill, New York. Plasticizer" International Scholarly Research Network ISRN Civil Engineering Volume 2012, Article ID 469272, 5 pages doi:10.5402/2012/469272 2005 .
[6] Ketan Shah, " Modular formwork for faster, economical and quality construction", Indian Concrete Journal, July 2005, Volume 79,Pg.6-23.

[7] "Formwork \& Scaffolding", CE \& CR, September 1992, Vol. 05, No. 9, Pg. 46-57.

[8] Ashok Mandal, "Scaffolding \& FormworkMaintenance \& Safety",CE \& CR, August 2006, Vol. 19, No. 8, Pg. 46-50.

[9] "Emerging Trends In Formwork And Scaffolding", CE \& CR, Sep 92,Pg.46-49.

[10] "ConstructionEquipment",CE\&CR,May1992,Pg.5052.

[11] IS14687(Falsework For Concrete StructuresGuidelines)

\section{BIOGRAPHIES}

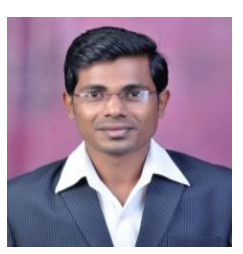

Sandip P.Pawar Completed B.E. in civil Engineering 2009 and M.E appear in Construction Technology \& Management in North Maharashtra University Jalgaon (MS).

P.M.Atterde (Department of civil engineering SSGBCOET Bhusawal) 